\title{
Volunteering in the Context of Women's Activism in Bosnia and Herzegovina
}

\begin{abstract}
The author analyses volunteering in Bosnia and Herzegovina, focusing on women's activism in connection with values associated with the concept of civil society, such as solidarity, equity, and reciprocity. Civil society in Bosnia and Herzegovina generally suffers from fragmentation, donor-driven approaches, insufficient transparency and low trust among the general population, all of which present obstacles to voluntary work, as does a legal framework which is certainly not conducive to volunteering. Unlike organizations that do no more than promote the interests of their members, or groups connected to or controlled by political parties, women's organizations are often seen as undertaking genuine activism. The author reveals differences in attitudes to volunteer work among individual women in organizations of varying sizes, explaining that those differences depend to some extent on women's locations, ages or experience. Both inter-group and intra-group dynamics, including women's networks, provide additional insights into voluntarism, especially with regard to the value of solidarity.
\end{abstract}

Zlatiborka Popov-Momčinović is an Associate Professor in the Faculty of Philosophy at the University of East Sarajevo.

\section{Introduction}

In this study the subject of volunteering is addressed by focusing on women's activism in Bosnia and Hercegovina's civil society in the postwar and postsocialist periods. Despite the flourishing of numerous civil society organizations (CSOs), matters of what are called 'NGOization', fragmentation, and a project-driven approach ('projectitis disease') remain as problems in Bosnia and Herzegovina $(\mathrm{BiH})$ just as they do in many other countries, due to the extensive and continuing international assistance and difficulties with democratic consolidationwhich in many cases lags behind. ${ }^{1}$ Women enjoy greater presence and are more vocal in civil society than they are in official political institutions and political

1 Rita Jalali, Financing Empowerment? How Foreign Aid to Southern NGOs and Social Movements Undermines Grass-Roots Mobilization, Sociology Compass 7, no. 1 (2013), 55-73, 60, DOI: 10.1111/soc4.12007. All internet references were accessed on 18 June 2020. 
parties, something many interpret as a consequence of political underrepresentation. ${ }^{2}$ In this study, volunteering is therefore addressed in the context of certain features of BiH's civil society and of women's engagement within it. Civil society values such as solidarity, equity, self-help, and autonomy have been shown to have positive effects on volunteering, yet such idealistic values face multiple obstacles. ${ }^{3}$ In $\mathrm{BiH}$, female activism and volunteering are made more complex and questionable by the country's low levels of social capital and trust and its fragmentation and low levels of membership. Government institutions favour male associations such as sports and veterans' groups. The legal framework too for volunteering is inadequate, and there is widespread misunderstanding of volunteering among the general public. Indeed, if people understood the concept better they might well have more faith in civil society, and there could be challenges to the widespread perception of female volunteering as a simple extension of what is perceived as their 'natural' duties.

I have researched women's activism in Bosnia and Herzegovina over different time periods, first during 2011 when I conducted twenty-two in-depth interviews for the purposes of my own doctoral dissertation on BiH's women's movement. I have used that material in this analysis, adding it to a second phase of deep and thorough research into women's networking which I undertook during 2017 with Lejla Somun-Krupalija and for which we had the support of the TRAG and OAK foundations. ${ }^{4}$ That second phase consisted of face-to-face and Skype interviews, work with focus groups, and document analysis. In addition, with Amila Ždralović I have recently conducted research in cooperation with the CURE Foundation and the Foundation for Economic Empowerment of Women. That work, done during 2019, was focused on marginal groups of women and their organizations, such as women in rural settings, Roma women, and women from small communities. ${ }^{5}$ In this present article my focus is on my own transcriptions of the interviews which formed the basis of that project.

The fact that the research relevant for this study was done at different times and with different aims has enabled a nuanced approach to the topic, for although volunteering was not the main research question, many female activists brought the subject up themselves, and sometimes it emerged as a question in semi-structured interviews, thereby providing a broader picture of women's activism. I analysed the connection between civil society and values such as solidarity, reciprocity, and equity, and their positive effect on volunteering. One of

2 Zlatiborka Popov-Momčinović, Ženski pokret u Bosni i Hercegovini. Artikulacija jedne kontrakulture, Sarajevo 2013, 117.

3 Colin Roshester / Angela Ellis Payne / Steven Howlett, Volunteering and Society in the $21^{\text {st }}$ Century, London 2010, 16.

${ }^{4}$ Cf. these foundations' websites at https://tragfondacija.org/en/ and http://www.oakfnd.org.

5 Cf. the CURE foundation's website at http://www.fondacijacure.org. 
my main findings is that women activists have somewhat different perceptions of volunteering depending on whether they belong to a larger or a smaller organization, and based on how they connect their volunteer activity to matters such as fragmentation, hierarchy, and solidarity. The data regarding those perceptions will be elaborated in detail in the context of the research literature.

\section{The Concept of Civil Society}

Frequently, the concept of civil society is highlighted in order to demonstrate a country's level of democracy or democratization. The origin of the concept of civil society is traceable in modern political theory as a critical tool against absolutism, and it became a popular concept again in the 1980s with the rise of protest movements under the authoritarian regimes in Central and Eastern Europe (CEE) and Latin America, both under authoritarian rule and during transitional periods. ${ }^{6}$ Under authoritarian rule, civil society stands in opposition to the non-democratic state, although in transition phases it is often characterized by cooperation with it for the sake of democratic consolidation. At such times, civil society maintains an important critical function, as a watchdog of the very process of change. In some cases, new political elites closely connected to or engaged within civil society during the authoritarian period attempted to derail it during the subsequent transition towards democracy. ${ }^{7}$ Such elites tend then to perceive civil society as a tool to overthrow an old regime, a sort of 'necessary good', but not as anything intrinsically connected to a democratic society. ${ }^{8}$

According to Larry Diamond's frequently quoted definition, civil society is the realm of organized social life that is voluntary, self-supporting, self-generating, and autonomous from the state. ${ }^{9}$ Scholars highlight the importance of those characteristics and values to civil society in Southeastern Europe too. Vukašin Pavlović has written that civil society is a normative ideal that includes different ethical principles such as autonomy, anti-hierarchy, solidarity, grassroots initiatives, pluralism, volunteering, self-initiative, humanitarianism, and self-help. ${ }^{10}$ According to Ismet Sejfija, there are four structural dimensions to civil society: formal and informal associations, values and principles on which civil society is based and which it promotes, social capital, and the public. ${ }^{11}$

\footnotetext{
6 Adem Jezard, Who and What is 'Civil Society'?, World Economic Forum, 23 April 2018, https://www.weforum.org/agenda/2018/04/what-is-civil-society/.

7 Huan Linz / Alfred Stepan, Problems of Democratic Transition and Consolidation.

Southern Europe, South America, and Post-Communist Europe, Baltimore/MD et al. 1996, 9.

8 Vukašin Pavlović, Civilno društvo i demokratija, Belgrade 2004, 235.

9 Larry Diamond, Rethinking Civil Society. Toward Democratic Consolidation, Journal of Democracy 5, no. 3 (1994), 4-17, 5, DOI: 10.1353/jod.1994.0041.

10 Pavlović, Civilno društvo, 80.

11 Ismet Sejfija, NVO sektor u BIH. Tranzicijski izazovi, Tuzla 2009, 53.
} 
John Keane, one of the most influential thinkers on civil society, points out that the meta-discourse or 'big narrative' of civil society is full of simplistic and dogmatic idealizations, ${ }^{12}$ which is the consequence of a well-established dichotomy with a 'long philosophical genealogy'.13 Early modern political thinkers saw a distinction between the state as a sphere of coercion, and civil society as a sphere of freedom. Under authoritarian rule the distinction was real in that civil society was suppressed in various ways and flattened. ${ }^{14}$ In periods of so-called democratization however, such dichotomy becomes dysfunctional. Seymour Martin Lipset has noted that functioning democratic institutions are of great importance for the development of civil society, and to ensure the presence of its values and prerequisites. Lipset focuses especially closely on social capital and trust, by which he means that if institutions are bound by the rule of law and perceived as accountable, people tend to trust each other more and consequently are more ready to form civil society groups and organizations or to involve themselves in them. ${ }^{15}$ Features of civil society such as solidarity, autonomy, self-help and anti-hierarchy must therefore be addressed within their specific contexts and in connection with other arenas of democratization, such as a functioning state, at least a relatively autonomous and well-valued political society, the rule of law, a state bureaucracy which a democratically elected government can use, and solid economic institutions. ${ }^{16}$

The mutual interaction of all those values must be analysed with full regard to their interconnectedness, and although to a great extent they are idealistic, they have a traceable impact on volunteering. According to certain studies a key set of values has, or might have, a significant impact on volunteering, and they include altruism (compassion or care), solidarity (responsibility for contributing to the wellbeing of the group and its members), reciprocity (helping others and sometimes receiving help in return) as well as equity and social justice-in other words the sense that inequality and injustice are agreed to be morally wrong. ${ }^{17}$

The end of state socialism in many Central East European countries was followed by proliferation of CSOs both in the number of them and in the different activities they undertook in the name of civil society. ${ }^{18}$ Certain scholars claim

12 Džon Kin, Civilno društvo. Stare slike, nove vizije, Belgrade 2003, 86. For the English original, cf. John Keane, Civil Society. Old Images, New Visions, Stanford/CA 1998.

13 Linz / Stepan, Problems of Democratic Transition, 9.

14 Vukašin Pavlović, ed, Potisnuto civilno društvo, Belgrade 1995.

15 Sejmur Martin Lipset / Džejson M. Lejkin, Demokratski vek, Belgrade 2006, 136-138. For the English original cf. Seymour Martin Lipset / Jason M. Lakin, The Democratic Century, Norman/OK 2004.

16 Linz / Stepan, Problems of Democratic Transition, 7.

17 Roshester / Ellis Payne / Howlett, Volunteering and Society, 16.

18 Ismet Sejfija, Povijesne predispozicije i aktuelni razvoj građanskih asocijacija u $\mathrm{BiH}$, Sarajevo 2008, 37. 
that although studies have been made of civil society in particular countries in Central Eastern Europe, there has been little systematic research and few comparative approaches. While after 1990 the new political setting and legal framework triggered a boom in CSOs, more recent changes in government in certain countries, such as Hungary, created volatile relationships, scepticism of and even repression of them. In several of the countries that once made up Yugoslavia, war stopped the development of civil society but then international humanitarian aid, financial and technical assistance facilitated it. In the CEE countries there is also a difference between EU members and non-member states. The figures for the first group of states show more members, a greater proportion employed in CSOs, more engaged volunteers, positive attitudes, and trust among the population. ${ }^{19}$

According to feminist studies, certain general features of civil society during transitional periods are marked by 'feminization'. Thus, during the authoritarian state socialist period men were distinguished as leaders of civil society and the so-called feminine question appeared unimportant. ${ }^{20}$ In the subsequent transitional period, former dissidents seized institutional power and the state withdrew from-or reduced-the functions it had performed during socialism, such as social care. However, there always came a time when the new societal structure proved incapable of solving the everyday problems of the citizens, opening up space for grassroots groups and organizations to mobilize themselves. ${ }^{21}$ Women, traditionally perceived as more sensitive to others' needs, gained more prominence than men in civil society. ${ }^{22}$ They entered civil society precisely to address those needs, as well as to enter the male-dominated public sphere and make their own voices heard. One of the problems, according to feminist scholars, is that civil society in the transitional (former socialist) countries became shorthand for women's unpaid work, ${ }^{23}$ although that is more true for the early transitional period (1991-1996). According to more recent studies, across the Central East European countries the contribution of civil society to

19 Michael Meyer et al., Patterns in Civil Society in Central and Eastern Europe. A Synthesis of 16 Country Reports and an Expert Survey, in: Peter Vandor et al., eds, Civil Society in Central and Eastern Europe. Challenges and Opportunities, Vienna 2017, 13-23.

20 Anna Titkow, Let's Pull Down the Bastilles Before They Are Built, in: Robin Morgan, ed, Sisterhood Is Global. The International Women's Movement Anthology, New York/NY 1996, 560-566, 566.

21 Grzegors Peitrowski, Civil Society and Social Movements in Eastern Europe, in: Heidi Moksnes / Mia Melin, eds, Global Civil Society. Shifting Powers in a Shifting World, Uppsala 2012, 118-124, 122.

22 Barbara Einhorn / Charlie Sever, Gender, Civil Society and Women's Movements in Central and Eastern Europe, in: Jude Howell / Diane Mulligan, eds, Gender and Civil Society. Transcending Boundaries, London et al. 2005, 23-53, 31.

23 Jacqui True, Gender, Globalization and Postsocialism, New York/NY 2003, 140-141. 
national GDP has grown and in some countries women's groups are considered one of the most influential and effective phenomena. ${ }^{24}$

In most transitional countries, a phenomenon occurred which might be called 'NGOization', meaning that very often civil society was equated with non-governmental organizations (NGOs). Many authors highlight that the concept is most often applied by international assistance practitioners who reduce civil society to professional non-governmental associations giving technical assistance. They therefore tend to overlook grassroots institutions, religious organizations, trade unions, community organizations, traditional leadership institutions and informal networks. ${ }^{25}$ Effectively, 'contentious groups were not "needed" by the regimes of the new and weak democracies', so that grassroots mobilization groups and social movements were easily marginalized. ${ }^{26}$

Although NGOs are obviously a valuable part of civil society, they are nevertheless only a 'subset of civil society, formally organized and registered' ${ }^{27}$ In fact too much reliance on them means that a distorted picture of volunteering tends to emerge, reducing civil society to an NGOs framework while measuring its capacities and reliability by using the standards of foreign donors. From that perspective, volunteering appears as another of the human resources of some organization or other, so is seen less clearly as having its own value and as being one of the normative ideals of civil societies mentioned above. ${ }^{28}$ The reductionist approach focusing on NGOs has therefore contributed to the creation of a distorted image of volunteering. In the following, I will therefore focus on women's activism within Bosnia and Herzegovina's civil society in the light of the notion of feminization of civil society. My aim is to seek contextualized insights into how volunteering is perceived and how it actually operates.

\section{Civil Society, Women's Activism and Volunteering in Bosnia and Herzegovina}

The narrow approach to what constitutes civil society is more strongly present in Bosnia and Herzegovina than it is elsewhere. The reason for that is the huge amount of international assistance with reconstruction there which began in

24 Meyer et al., Patterns in Civil Society, 19-21.

25 Randall Puljek-Shank / Willemijn Verkoren, Civil Society in a Divided Society. Linking Legitimacy and Ethnicness of Civil Society Organizations in Bosnia-Herzegovina, Cooperation and Conflict 52, no. 2 (2017), 184-202, 185, DOI: 10.1177/0010836716673088.

26 Peitrowski, Civil Society and Social Movements, 122.

27 Ivana Howard, Building Civil Society in Bosnia and Herzegovina. Challenges and Mistakes, in: Eldar Sarajlić / Davor Marko, eds, State or Nation? The Challenges of Political Transition in Bosnia and Herzegovina, Sarajevo 2011, 93-126, 96.

28 Fadil Šero / Milan Mrđa, Osvrt na današnju sliku i dostignuti nivo razvoja nevladinog sektora u BiH, in: Milan Mrđa, ed, Civilno društvo i lokalna demokratija, Sarajevo 2001, 114. 
the form of humanitarian aid during the war of 1992-1995. Not only was a large amount of money distributed through NGOs, but the very registration of certain NGOs happened precisely to address the requirement of international organizations for local partners in the field..$^{29}$

Foreign influence is clear too from the fact that only $10 \%$ of the currently registered CSOs existed before the war. ${ }^{30}$ That does not mean that international actors were operating in line with some 'hidden agenda', nor does it deny the positive benefits of assistance. ${ }^{31}$ Rather, it raises the problem of a discrepancy between 'local and donor legitimacy constructs'. ${ }^{32}$

Soon after the war the vast majority of projects by foreign NGOs and organizations addressed the areas of reconstruction and the delivery of humanitarian assistance to citizens, while analogous areas of interest were held by local NGOs. With the passage of time, local NGOs supported by foreign donors professionalized. However, matters of human rights and discourses of 'gender equality', 'human rights', 'Roma rights' and 'LGBTQ rights' have been perceived by local actors as being too abstract, and not addressing concrete-and pressing-problems. ${ }^{33}$

The numbers reveal how CSOs have blossomed, for it was estimated in 2016 that there were more than 23,000 of them registered, a substantial increase from about 12,000 in 2013. The most numerous are sports clubs and pastime-related associations, while associations for the protection of women comprise $7.3 \%$ of registered CSOs. However, it is estimated that the ratio of active to inactive organizations is about $1: 2$ or even 1:3, because by law organizations must pay 'winding-up' fees to shut themselves down, and many CSOs refuse to pay. ${ }^{34}$ During the interviews conducted in 2011, female activists described the trend:

'There was an expansion in terms of registration, and foreign donations were strengthening the capacity of organizations, but when they withdrew, they [i.e. the CSOs] did not manage to survive. I have not got any information on the number of women's organizations; we could come up with estimates of course, but it needs to be investigated properly. It is difficult for us, because an association could be registered

29 Sejfija, Povijesne predispozicije i aktuelni razvoj građanskih asocijacija u $\mathrm{BiH}, 39$.

30 Howard, Building Civil Society in Bosnia and Herzegovina, 101.

31 Jalali, Financing Empowerment?, 59.

32 Puljek-Shank / Verkoren, Civil Society in a Divided Society, 192.

33 Puljek-Shank / Verkoren, Civil Society in a Divided Society, 192; Sejiija, Povijesne predispozicije i aktuelni razvoj građanskih asocijacija u $\mathrm{BiH}, 39$.

${ }_{34}$ Zilka Spahić-Šiljak, Country Report. Bosnia and Herzegovina, in: Peter Vandor et al., eds, Civil Society in Central and Eastern Europe. Challenges and Opportunities, Vienna 2017, 188-203, 189, 194-195. 
at all sorts of levels; it will be a huge job to go through them all, and find out which of them are still active. ${ }^{35}$

'[...] one official said that there are more than 2,000 women's associations in $\mathrm{BiH}$. That's why the first thing we did was go to the Ministry of Justice in 2008. They have got 12,808 NGOs registered now. Anyway, that was when we started with the questionnaires, because we have got a network in the field so that we reach whatever the exact number is that there are. We ended up sending more than 300 questionnaires, and we got ninety-nine back from organizations. Some of then had not got a website, say, and some just had no idea! But anyway we tried to get feedback from everyone involved with women's issues. With the registered ones, we tried to see the key realities for them, but when you look at the questions and the answers we got, things like, "is there a women's network?" or a women's movement; they really do not know. And, just look at how many organizations just shut down. It was devastating $[\ldots] .{ }^{36}$

The largest growth occurred after the war ended in 1995, while more recently there has been a significant tendency to strengthen technical, administrative, and management capacities, as well as to seek gender balance in the management of CSOs. ${ }^{37}$ However, there is a huge gap between these more technical aspects and the real impact of CSOs on people's everyday lives. ${ }^{38}$ Compared with Central East European countries, the population of $\mathrm{BiH}$ and in fact of the Balkan region as a whole is more critical of international support, which was 'partially perceived as the installation of a donor-driven "parallel system of CSOs"'. ${ }^{39}$ In the earlier research, half the NGOs acknowledged that they were completely oriented toward donors. ${ }^{40}$

The criticism of civil society in $\mathrm{BiH}$ can be further elaborated from the types of organization. Certain scholars group CSOs into three categories. The first, and most numerous in $\mathrm{BiH}$, is oriented towards the interests of its members but subservient to the interests of political parties and the government institutions from which they receive their grants. The most notorious case is that of war veterans' associations. The second category is comprised of think tanks, while the third-much less well supported by government funds-is made up of

\footnotetext{
35 Interview conducted on 16 September 2011 in Bihać.

36 Interview conducted on 3 February 2011 in Sarajevo.

37 Goran Žeravčić, Razvoj civilnog društva u BiH pod utjecajem Europske unije, Belgrade 2018, 161 .

38 Tijana Dmitrović, Izazovi civilnog društva u Bosni i Hercegovini. Analiza i preporuka za politike, Sarajevo n. d., 3.

39 Meyer et al., Patterns in Civil Society, 18.

40 Šero / Mrđa, Osvrt na današnju sliku i dostignuti nivo razvoja nevladinog sektora u $\mathrm{BiH}, 134$.
} 
grassroots associations, most of them small scale, and most having no full-time employees. $^{41}$

As for women's organizations, it is certainly true that at local level especially only symbolic amounts of money are allocated to them. There is another problem too, concerning the lack of transparency of selection processes for awards of grants of local public funds, nor is there any measurement at all of the impact of whatever funds are allocated. ${ }^{42}$ Women activists themselves confirmed that point in interview, one for example stressing their orientation towards foreign funds because of how procedures and rules are defined when applying for grants:

'When we complained to the Council that they were not giving associations anything, they said, "That is not true, we gave money to basketball players, fishing clubs and things like that." When we go to the NGOs, they say, "Oh, go to the mayor! Ask him; and while you are at it have a little cry!" So we got used to working with foreigners; and of course they have a procedure. Actually, what it comes down to is: I really do not know what to do without that procedure. ${ }^{\prime 43}$

That problem was further confirmed in our most recent research from 2019, when activists again emphasized that substantially more money from the local budget is allocated to men's activities. One activist pointed out that a structural 50/50 ratio ought to be introduced: 'This is one of the issues that should be raised by the women's lobby group; state--and city-financing of women's associations etc. These are the open issues that need to be addressed, and they need to be raised soon, to prevent closures ...' ${ }^{44}$

The fact that associations based on members' common interests receive most government support and that many grassroots associations are oriented towards foreign donors contributes to people's distorted and somewhat cynical picture of civil society and their lack of interest in what they do, let alone in the idea of making a contribution themselves, which might include volunteering. ${ }^{45}$ According to an activist from Banja Luka, the image of NGOs in the media and among the general public is very poor because many people are convinced that the non-government sector exists solely to further person-

41 Dmitrović, Izazovi civilnog društva u Bosni i Hercegovini, 7-8; Goran Žeravčić, Mapping Study of CSOs in Bosnia and Herzegovina, Sarajevo 2016, 6.

42 Žeravčić, Mapping Study of CSOs in Bosnia and Herzegovina, 62.

43 Interview conducted on 22 October 2011 in Višegrad.

44 Interview conducted on 26 March 2019 in Tuzla; cf. Amila Ždralović / Zlatiborka Popov Momčinović, Activisms on the Margins. Capacity Assessment in Ten Selected Women's Organisations, Sarajevo 2019, 30.

45 Amila Ždralović, Društveni aspekti političkog sistema, in: Damir Banović / Saša Gavrić, eds, Država, politika i društvo u Bosni i Hercegovini. Analiza postdejtonskog političkog sistema, Sarajevo 2011, 179-200, 200. 
al interest. ${ }^{46} \mathrm{~A}$ woman activist talked of a communication problem between CSOs and the general public: 'We made a big mistake because we did a lot but we did not truly reach out to women. Many still do not know what was done, what the women's movement did; the younger generations especially are not aware of it. ${ }^{47}$

Field studies throughout $\mathrm{BiH}$ confirm that volunteerism is misunderstood, many seeing it as a form of free or exploitative labour rather than as something beneficial to individuals and the community. ${ }^{48}$ Research has pointed up the lack of transparency of CSOs, and many believe women's organizations are closed to non-members. ${ }^{49}$ Yet in order to recruit volunteers any organization must be open. It must be consultative, and patient if it is to build trust among those willing to work in partnership with it. ${ }^{50}$ The literature notes the use of NGO jargon in project applications in which non-members of women's NGOs are referred to as 'beneficiaries' and 'users'. That is revealing of how they are perceived as being in passive receipt of support and help ${ }^{51}$ which in turn reduces motivation to include other women, some of whom might be willing to act as volunteers themselves. Projectization and 'managerial conservatism' have been confirmed in numerous countries as obstacles to broader political involvement. ${ }^{52}$

Lack of motivation to volunteer is further strengthened by inadequate legal frameworks. While the legal conditions for the formation of a civil society association were met by a law passed in 2001, there is no state law covering volunteering. ${ }^{53}$ In fact, the first laws on volunteering were introduced in Republika Srpska in 2009, not until 2012 in the Federation of Bosnia and Herzegovina $(\mathrm{FBiH})$, and still have not been introduced in the Brčko District-and nowhere at state level. ${ }^{54}$ The law in $\mathrm{FBiH}$, moreover, did not take into account the experience of the implementation of the first law; there was no engagement to research the flaws, benefits and practical experiences of it. ${ }^{55}$

It is worth pausing here to consider why a law on volunteering is important for the encouragement of citizens to volunteer. A high level of unemployment

46 Sježana Karić, Civilno društvo zakazalo. Britanski list 'Ekonomist' svrstao BiH pri dnu tabele po pitanju demokratije, Srpska info, 22 January 2019, https://srpskainfo.com/civilno-dr ustvo-zakazalo-britanski-list-ekonomist-svrstao-bih-pri-dnu-tabele-po-pitanju-demokratije/.

47 Interview conducted on 21 September 2011 in Višegrad.

48 Spahić-Šiljak, Country Report. Bosnia and Herzegovina, 195.

49 Elissa Helms, Gendered Visions of the Bosnian Future. Women's Activism and Representation in Post-War Bosnia and Herzegovina, Pittsburgh/PA 2003, 108.

50 Roshester / Payne / Howlett, Volunteering and Society in the $21^{\text {st }}$ Century, 204.

51 Popov-Momčinović, Ženski pokret u Bosni i Hercegovini, 137.

52 Jalali, Financing Empowerment?, 61.

53 Ždralović, Društveni aspekti političkog sistema, 191.

54 Forum mladih SDP, Radno iskustvo svima. Javna politika, http://www.sdp.ba/datoteke/ uploads/PRILOG-1-Javna-politika-RIS-1.pdf.

55 Forum mladih SDP, Radno iskustvo svima, 11. 
in Bosnia and Herzegovina, especially among young people, means that the law is often viewed first and foremost in the context of acquiring essential skills and contacts that can be formally documented and thus foster subsequent employment. Volunteering is similarly defined in both the existing laws, the $\mathrm{FBiH}$ law stating that volunteering is considered to be 'a voluntary provision of personal time, efforts, knowledge and skills for the purpose of rendering services or activities, without compensation, for the common good of the Federation of $\mathrm{BiH}^{\prime}{ }^{56}$ The law in Republika Srpska states:

'In terms of this Law, volunteering is an organized voluntary activity or provision of services or performance of activities with the aim of general and common welfare or welfare of another person without monetary compensation or material gain, unless otherwise provided by the Law. ${ }^{57}$

However, the literature on volunteering challenges the conventional wisdom that volunteering presupposes the absence of remuneration. Volunteering is un-coerced and altruistic activity, productive for volunteers and others: 'If people are compensated the amount of payment in cash or in-kind is significantly less-than-market-value. ${ }^{58}$ Voluntarism is a two-way process from which the volunteer derives benefit such as personal fulfilment, acquisition of experience, social recognition and social contacts. ${ }^{59}$

Despite the entity laws, however, volunteering remains little known and is unsupported by the respective governments. For example, no ministry did anything to promote the law nor the importance of volunteering, and there was no encouragement for state institutions to accredit themselves. NGOs remain the only organizations that have been accredited and which have provided opportunities for young people to gain work experience through volunteering. ${ }^{60}$

A United Nations (UN) Volunteers Report describes forms of voluntary work often left out of surveys, including community self-help and campaigning or advocacy work, as well as more traditional forms of volunteering not organized by modern CSOs-the so-called 'hidden volunteering' ${ }^{61}$ The

56 The Law on Volunteering, Official Gazette of BiH 110, 21 December 2012, Art. 3.1.a, https://mladi.org/v2/en/projects/3/the-law-on-volunteering-fbih/7549-fbih-law-on-volun teering-enters-into-force.

57 Law on Volunteering of the Republic of Srpska, Official Gazette of Republic of Srpska 89, no. 13, n. d., art. 3, http://www.vladars.net/eng/vlada/ministries/MFYS/Documents/Law\%20 on\%20volunteering_129353446.pdf.

58 David H. Smith / Robert A. Stebbins, Introduction, in: David Horton Smith / Rebert A. Stebbins / Jurgen Gratz, eds, The Palgrave Handbook of Volunteering, Civic Participation, and Nonprofit Associations, Houndmills et al. 2016, 1-20, 10.

59 Roshester / Ellis Payne / Howlett, Volunteering and Society in the $21^{\text {st }}$ Century, 18.

60 Forum mladih SDP, Radno iskustvo svima, 12.

61 Spahić-Šiljak, Country Report. Bosnia and Hercegovina, 195. 
report notes that some volunteering is hidden only because of inadequate data and mentions that certain surveys approached volunteering incorrectly. Furthermore, perceptions of volunteering are skewed because many staff in $\mathrm{BiH}$ NGOs officially work as volunteers because of the high employment tax of approximately $69 \% .{ }^{62}$ Another source of inaccuracy is that statistical offices keep no record of numbers employed on short-term consulting contracts, nor of volunteers. ${ }^{63}$

Given the prevailing patriarchal perceptions within BiH's society, women's work in civil society is often perceived as an extension of their 'natural' duties, such as the care and nurturing of others. ${ }^{64}$ The concept, normative ideals, and values of civil society, including volunteering, thereby become ever more complex and ultimately dubious for both citizens and researchers. Some women pioneers in civil society realize that even when their work is recognized, such recognition is used as a strategy for their exclusion from the official institutions by which the most important political decisions are made. ${ }^{65}$ As one activist put it:

'Our traditional norms situate women in the private sphere, which is primarily about caring for children, the elderly, the disabled, and that is the context women are much more active in in civil society, because that is also about caring for others. It is a consequence of the patriarchal understanding of the role of women, so women are less present in political institutions but more visible in civil society. ${ }^{\prime 66}$

Some activists tend to idealize their own work and their dedication to the public good, making generalizations about the impact of their work on civil society as a whole. One of the female activists we interviewed made a point expressed by many others too, saying, 'if NGOs were shut down for just one day, the whole system would collapse'. In her opinion, 'it is thanks to CSOs that food is provided every day to the hungry, that assistance is given to the elderly and the sick' ${ }^{67}$ Another activist described the same situation in gendered terms: 'Women are more sensitive, so there are more of them in civil society, because civil society helps others.' ${ }^{68}$

62 Spahić-Šiljak, Country Report. Bosnia and Hercegovina, 195.

63 Žeravčić, Mapping Study of CSOs in Bosnia and Herzegovina, 55.

64 Helms, Gendered Visions of the Bosnian Future, 35.

65 Popov-Momčinović, Ženski pokret. Žene i procesi pomirenja u Bosni i Hercegovini, 36.

66 Interview conducted on 15 September 2011 in Banja Luka.

67 Izabrano novo rukovodstvo NVO Vijeća, Žurnal info, 12 April 2011, https://zurnal.info/ novost/6504/izabrano-novo-rukovodstvo-nvo-vijeca.

68 Interview conducted on 26 September 2011 in Derventa. 


\section{Perceptions of Women Activists}

In interviews with women activists in the different research periods, to gain insight into volunteering's connection to values we examined the capacities of certain women's organizations, along with the presence of normative ideals associated with the very notion of civil society, such as solidarity, commitment, equity, and autonomy. I found during my own research that when they addressed those normative ideals the women tended to make a distinction between wartime and postwar activism, and that their perceptions varied depending on whether they were from larger or smaller organizations, or based in urban centres, smaller local communities or rural areas, while for some of them, age and experience made a difference.

\section{The War and the Postwar Years}

During the war of 1992-1995 many women's groups were created, most of them informal. Women established their own networks of survival, mutual support, and opposition to war policies. Some activists still prominent today began their work or their cooperation with international organizations and donors in order to help the general population. This statement by one of them sums up what others said, too:

'We first got together informally, during the war. The idea was to help those of our own citizens who were leaving as well as refugees and displaced persons who were arriving. [...] When war broke out, women looked after others: they healed wounds. [...] The war brought many misfortunes; we established an informal group in 1992.

We had a group in every village -800 women members. We helped the wounded, and refugees.' 69

In spite of the boundaries to women's activism imposed by the war itself, activists at that time succeeded in providing alternative spaces for women to meet, regardless of their ethnic or other affiliations, and through such encounters set up the first initiatives on peace-building and reconciliation. ${ }^{70}$ The women's activities were primarily humanitarian, but included sustained protest. ${ }^{71}$ They were voluntary, and were accompanied by public actions designed to avoid any co-opting, and they refused to adopt the logic of ethnic categorization and hierarchy. Although the turbulence of that period means that the very

69 Popov-Momčinović, Ženski pokret u Bosni i Hercegovini, 112.

70 Ristin Thomasson, To Make Room for Changes. Peace Strategies from Women Organizations in Bosnia and Herzegovina, Stockholm 2006, 16.

${ }^{71}$ Margarita Papandreou, Are Women More Peace-Loving than Men?, in: Biljana Kašić, ed, Women and the Politics of Peace. Contributions to a Culture of Women's Resistance, Zagreb 1997, 41. 
notion of voluntarism cannot be precisely addressed, it is nevertheless obvious that women entered the public sphere in order to oppose coercion and to help others while not expecting anything for themselves in return. For their part, the activists interviewed mentioned values such as solidarity that have been shown to have an impact on voluntarism. According to one pioneer of the women's movement, during the war there was more energy in the population, and the beginnings of civil society were driven by solidarity, mutual help and a sense of belonging:

'I mean, it is stupid, but I miss wartime because there was solidarity. How can I explain it? You see, you are terrified, but then we all felt it ... But now, everything is ... Well, in the first place we have got unfinished business with history-after the war, you know? And I do not see how it will be resolved because first of all there is no willingness; then you have got no motivation, there is no energy. [...] These days everybody is just pursuing their own projects. In Yugoslavia we used to get together, we would meet up and talk; but now we cannot even get together in our own town. ${ }^{.72}$

Another activist, from Mostar, made a different connection between the war and the immediate postwar period. So that they could continue to provide help to people, they decided to register a local NGO:

‘...] most of the team was involved in work with international organizations while the war was on. During the war we were working with women refugees in collectives throughout western Herzegovina, and when the first people started to return, the people we were trying to help were not at all sure what was going on, because they were not going back to their old homes but to alternative accommodation. And somehow they seemed to think it was normal that we would be there to help. Then the donor withdrew. We had the area from Glamoč to Stolac, and we had people relying on us; but we had gained that trust, that was our basis. So we decided to establish a local NGO [...].,73

The war helped women recognize their own oppression and marginalization and especially to connect domestic violence with sexualized violence during the war. As one activist and feminist theoretician notes: 'Domestic violence is caught in a vicious circle of mutual consequence and causation, along with patriarchy and war. ${ }^{74}$ An activist from Tuzla described the connection as follows:

'Let us say you consider yourself a lucky woman if your husband does not drink, does not yell at you, does not beat you, lets you spend a bit of money ... And that is considered good! But you know, we gained a lot in the war and we said really, we benefitted from it ... [because, Z. P. M.] we received a lot of education. I mean, when

72 Interview conducted on 9 February 2011 in Sarajevo.

73 Interview conducted on 5 September 2011 in Mostar.

74 Zorica Mrsevic, The Opposite of War is not Peace. It is Creativity, in: Marguerite R. Waller / Jennifer Rycenga, eds, Frontline Feminism. Women, War and Resistance, New York/NY et al. 2001, 43-57, 44. 
I went to Norway to see what women's rights really are I had to face up to my own prejudices-and I was one of the intellectuals $[\ldots] .{ }^{75}$

Women first began to meet during and soon after the war, to listen to each other, first sharing their own stories before moving on to politics. Their initiative led to the opening of doors to activism in other fields, such as political participation, economic empowerment, and resistance to domestic violence. ${ }^{76}$ The proliferation and professionalization of women's groups has changed not only how they work but also the perceptions of activism itself, and in certain cases reference to volunteering is used to describe the changes. However, given the uncertainty of the wartime context of ever-present structural and direct violence and then the changes that began after the ceasefire, it is difficult to say that the activism was voluntary during the war, and in the postwar period less voluntary or perhaps not even voluntary at all. I will now focus therefore on the period after the war and on women activists' perceptions of their engagement in civil society, including their views on volunteering and its accompanying values.

\section{The Views of Activists from Small and Large Women's Associations}

During each of the research projects involved in this study, there was a clear difference how activists working in large from those working in small organizations saw things. However, it is far from inherently obvious how we should define what is a large and what a small organization. As one activist put it:

'The environments they work in are different. There are villages and small towns and large organizations, and large urban centres and small organizations that have not come close to doing what others have accomplished in small environments. ${ }^{\prime 77}$

For this article I have relied on what activists themselves think, trusting their view of the size of their own and other organizations. I believe there is a tendency to call an organization 'large' or 'small' depending on the number and value of donations and funding they receive, itself sometimes connected to whether they work in larger urban centres or smaller towns and rural areas. According to activists who refer to their organizations as 'small', those factors are interconnected since organizations in larger urban centres-especially Sarajevo and Banja Luka-have easier access to foreign donors and are better placed to meet such donors both formally and informally.

The two groups of organizations depict volunteering itself somewhat differently. All activists showed a tendency to highlight their own volunteering, but depending on their specific organization they described it differently. Most of

75 Interview conducted on 26 March 2019 in Tuzla.

76 Thomasson, To Make Room for Changes, 32-36.

77 Interview conducted on 6 September 2011 in Trebinje. 
those who perceived their organization as 'large' noted that they had no wish to depend on donors for every activity, while those who perceived their organization as 'small' made no mention of the point either because they had no donors or because any funding they did receive was insufficient for them to be similarly selective. However, in general they described the work of organizations with reference to the funding they received, which proves the prevalence of the donor-driven approach of CSOs. According to one activist from a larger organization, certain organizations have no donors at all and their engagement in civil society is purely voluntary. In that activist's opinion such organizations have no effect on improving the position of women:

'They simply get together, socialize, talk, exchange experiences; but they do not want to apply for a donation. [...] Then there are organizations that not only are not feminist but actually they are just places where women get together-to make jam, say; you know? "Food for the winter". And that is how they reaffirm all the stereotypes that exist in our society. ${ }^{78}$

Activists from smaller organizations tend either to idealize their position in terms of being 'pure' volunteers-or they complain. In fact very often they alternate between the two when talking about their own work. They highlight the lack of solidarity, the problems of fragmentation and of hierarchy among women's groups, as well as all the chasing after donations. One activist working for a now-defunct organization revealed appropriately ambivalent attitudes:

'Associations that have grown and got stronger think: "They are too small for us, we are not going to cooperate with them" [i. e. with the organization to which the interviewee belonged, Z. P. M.]. But absolutely everything we organize is voluntary, and that is it. Our work involves educating women, training them for work they can do at home-weaving, sewing [...] so we strive to market what they can produce through exhibitions and magazines. I mean, it is only symbolic, really ... [The organization] Medica is the strongest here [in Zenica]. That one's grown into a top-notch outfit, and we are too small for it to be considered as a partner. But we respond to all their projects and activities. I personally expected they would sometimes work with us but they never did. In Zenica, the problem is that many organizations, even if they have a specific area as a goal within their statute, they mess around in other areas. [...] We just like to hang out, and help. That was our motive-humanitarian work to help people. We knew how to clean out our wardrobes, how to collect food and parcel it up, we knew how to connect with local communities and share the stuff.

Then again, our goal is also moral support for our members, we have all got some problem or other of our own. Every year we organize events for our children with New Year's presents. We recently had an event where we sold children's drawings and we donated the income to the Sick Children's Association. We collected books and distributed them; but of course we had no idea what textbooks were used in schools, so we gave that one up. [...]

78 Interview conducted on 3 September 2011 in Sarajevo. 
Now there is less money for ever more organizations. People think associations are where money is actually made, and that it is the association that actually helps people financially [by providing salaries, Z. P. M.]. Furthermore, funding for women has decreased a lot and what there is, is usually reduced to just one segment. So associations are not sticking to their mission, but say, "Let's just go for what there is"..79

The palpable disappointment in this lengthy quote was transmitted directly to us as researchers during our field work in 2011. Activists in small organizations very often stressed that they worked purely voluntarily; and they complained about being contacted for the purpose of our research while being left out of projects. They even felt exploited, as revealed by the following e-mail sent to me:

'Dear Madam,

I forwarded your questionnaire to my friends but I am not optimistic about the number of answers, because there really are too many questions and too many questionnaires that we get in our association. Usually, they remember us when they want to send a questionnaire, but then we get passed over for projects that could involve us, although I recognize that there are exceptions. Our work at the Association is purely voluntary, nobody is paid to work here and we are mostly self-funded through our own participation. But I will put myself at your disposal as much as I can. ${ }^{\prime 80}$

Another woman activist highlighted various problems she and her colleagues had faced. They are a small organization, still active, and have managed to survive on the civil society market, meaning that they have been accepted by certain donors and have become engaged in projects run by larger organizations. This activist described how the members of her association, most of them in work as schoolteachers, did not see volunteering as a full-time activity. She praised their work as volunteers, delighting in the way they had managed to gain recognition in their local community and attract others, especially younger people, to volunteering. She too criticized the agenda set by donors and deprecated the tendency of international practitioners to perceive organizations like hers as less reliable, while simultaneously holding larger organizations to less critical standards. Stressing the value of solidarity, she described the large number of registered women's CSOs in positive terms:

'For example, it is a problem sometimes that we have not got any full-time employees, because it seems some donors do not take us seriously. Yet I guarantee that we, as volunteers, work and engage in an extraordinary way because we do not have set working hours and everything we do we do out of our passion for what we do. [...] We are a bit afraid of getting involved in bigger projects, or calling in professionals, because our funding is insecure-it is all short-term [...]. So an approach like that is frivolous really, because whoever decides does not actually get how things are on the ground. They do not think about how many smaller organizations from small

79 Interview conducted on 2 September 2011 in Zenica.

80 E-mail received on 5 September 2011. 
places can contribute more-and want to contribute more. [...] We encourage young people to volunteer [...] We also cooperate with other organizations locally, such as youth organizations [...]. I honestly cannot say we have had bad relationships with anyone, and over the years we have created our own image, based on what we do, and now many consider us a partner. They need us, and we need them [...]. And yes, we would like $[\ldots]$ to expand those networks $[\ldots] .{ }^{\prime 81}$

Smaller organizations have a more fluid structure and-not only by way of project terminology - a heterogeneous character which apparently motivates members to be more active and engaged. As one said, 'Our structure is different because we have got professors, we have got women doctors; but we have also got housewives. And everyone is really engaged, and helpful. ${ }^{82}$

During our research in 2019 we focused on smaller organizations as well as organizations representing vulnerable groups of women such as Roma and women living in rural areas. It then became ever clearer to us that for smaller organizations it is difficult to discern members of the organizations from beneficiaries of their work. ${ }^{83}$ Certain organizations have a 'fluid' structure, engage in a wide range of activities and offer other women help daily both in their own small communities and neighbouring ones. There are a great many problems in $\mathrm{BiH}$ with infrastructure, social services, education, and the medical system; indeed, much of what such organizations do ought actually to be provided by the state. Although our investigations did not include which activities were funded and how much money they received, the interviewees pointed out that some of it was done voluntarily, which is to say, without funding.

Two cases of interest for this study are the organization Jadar operating from Konjević Polje, a village in northeastern Bosnia-Herzegovina, and Viktorija from the small community of Pale to the east of Sarajevo, actually a part of East Sarajevo, in Republika Srpska. Each organization has a homogenous ethnic structure, the first consisting of Bosniaks and the second of Serbs. The first group cooperates with associations of Serb women from neighbouring communities, bringing together activities to bolster the economic empowerment of women and efforts at reconciliation in that part of the country. The second works in a mono-ethnically Serb region and is focused on its members' activities. Both organizations have been included in the activities of larger organizations and both appreciate the support they receive, although there are differences. Registered in 2003, Jadar has been active for longer, so that its members have a certain amount of insight into how civil society functions and greater understanding of relations among women's associations. Moreover, Jadar includes both retired

\footnotetext{
81 Interview conducted on 26 September 2011 in Derventa.

82 Interview conducted on 9 October 2011 in Kakanj.

83 Ždralović / Popov Momčinović, Activisms on the Margins, 29.
} 
women and a number who are still working. The women of Pale's Viktorija organization, which was registered in 2017, are all young.

By contrast with the often larger and better known women's associations, neither Jadar nor Viktorija has any strategic plan nor related documentation, nor is either's approach project-driven. The women of both organizations meet and praise the value of mutual support through kinship. Jadar is active in empowering the women of Konjević Polje through agriculture, its members supporting each other in promoting and selling their products. In Pale meanwhile, the younger and better-educated women of Viktorija mostly organize meetings, workshops, cultural events, and like to promote a healthy lifestyle. Jadar's women are not slow to offer criticism of the municipality, something Viktorija's members are less concerned with doing. Women activists from both organizations claim that more support from local government funds is allocated to associations meant for men. Generally, 'as we "descend" to the lower levels of legislation that aim at defining and concretizing gender equality policies, more often than not the original, declarative commitment to gender equality is "diluted" rather than put to practice'. ${ }^{84}$ This has more impact on small women's organizations from smaller communities than it does on larger, professionalized organizations that work at higher administrative levels.

Members of both Jadar and Viktorija value and practice solidarity, self-help and mutual support. We saw a tendency for Jadar's members to criticize some (but not all) larger organizations, which spend a great deal of money on conferences for example, or other things with no real impact on women's everyday lives. The view of an activist we interviewed from Pale revealed how a number of women, especially young women and those working within smaller organizations, understand civil society and volunteering. Contrarily to the state of affairs in 2011, when it was mostly the activists from smaller organizations who complained, by 2019 we found the opposite was true: now the complaints were coming from the larger organizations. It is difficult to explain why that was, but it might have been because when we interviewed its representatives Viktorija had been established only recently, and was included in some activities of larger NGOs. Moreover, its members were young, educated women most of whom were employed elsewhere. For them, volunteering was essentially a leisure activity:

'Actually, we had no great expectations; we wanted to socialize, travel together, share knowledge and tell each other our experiences, just to help each other. Any big ideas-well, we certainly have not got them now, given the current situation in the country, in our area, and with everything as it is. We all know everything depends on funds. [...] During the two years we have existed we have organized quite a few activities; in fact we are one of the most active associations in Pale at the moment, but

84 Amila Ždralović / Zlatiborka Popov-Momčinović / Zarfa Hrnjić-Kuduzović, Women in BiH Institutions Puppets of Gender Quotas, Sarajevo 2018, 10. 
like other people we simply have not got the big money behind us. What we have got is just symbolic, really but that does not bother us too much; we can still do our work, we just organize it as we can. Right at the start I reconciled myself to the fact that people, well ... that we do not expect any large funds: we have just got to work with what we have got and that is all there is to it [...]. We do everything voluntarily. Sometimes we get funding for expenses for things we organize [...]. It has happened that we go on some trip and someone cannot afford it. As far as earning, there is none [...] people sometimes act as if they are going to get rich in the non-governmental sector but that is rare. We all do this in the first place because we love it. I invest quite a bit of myself in the association, in all of these activities. I spend quite a bit of my own money on it, but I guess I just have that kind of voluntary spirit. ${ }^{85}$

In the interviews conducted in Sarajevo and Banja Luka, activists from larger organizations often highlighted that they did indeed help smaller ones and that they did so voluntarily. They said that they helped them register, included them in their activities and shared knowledge and know-how with them:

'The CURE Foundation strives to work with other organizations and help those that simply do not know how to register, and write up projects and so on. I would like to mention an interesting example. Some girls from Travnik - these were a group of girls who attended our educational activities-when they heard what we do they realized that there is no similar organization in Travnik, there is no feminist one that engages with women's rights, and with young people in an alternative way, in a feminist way. And they wanted to set something up. So the CURE Foundation has helped them, so much so that now they are going to register. Very cool girls, they are, too! We collaborate with them, we invite them to meetings and when there is anything to do in Travnik, like a workshop, we get in touch with them and they organize it. And that is how women's organizations should collaborate. Stronger organizations helping the weaker ones, just like I mentioned for urban areas: there, organizations have gone through a ton of things and procedures and now they have got to help rural people because understandably they are not yet on the same level. But then, they have not got the same problems and needs, either. ${ }^{86}$

‘We have assisted younger groups in their development and work, some organizations are starting up and closing fast, but that is because they did not have the commitment and were just chasing projects. We have cooperation beyond projects, and not just during them. ${ }^{87}$

Larger organizations with enough resources of their own, including financial support, continue to carry out certain activities voluntarily, without funding. One activist from Sarajevo connected that with the usual time limitations of projects and the practice of some donors who no longer consider important certain activities they used to support:

\footnotetext{
85 Interview conducted on 27 February 2019 in Pale.

86 Interview conducted on 3 February 2011 in Sarajevo.

87 Interview conducted on 15 September 2011 in Banja Luka.
} 
'Dependence on donations is a big problem because for example you can have a project activity which is super, phenomenal, but which requires more time than what the donors allow. For example to renew the women's movement will take at least ten years but donors come along and say, "Well, that problem is in the past, so let us take on a new one". Nowadays it is harder and harder and there are some things which at CURE we have decided we will never allow donors to influence. For example, we organize the Pitchwise Festival ourselves, which is not a project activity; its actually sixteen days of activism. ${ }^{\prime 88}$

A similar kind of voluntary work was confirmed in the case of the Horizonti organization from Tuzla, which was first established informally in 1994 and then formally in 1999. During that period Horizonti focused on psychological aid for women and their children who had survived violence during the war. It continues to provide its services voluntarily, although the focus is now on women's rights and political representation:

'We do psychotherapy voluntarily now. As a psychotherapist, since 1994, when a woman comes to me, I cannot tell her we do not do it anymore, donors do not recognize it anymore - so we do it. We have a psychologist here, and Ena and Jaca have finished [their studies, Z. P. M.], so we complement each other, we do thirty psychotherapy sessions over the course of a year, which are not on any of the lists, but it has given our organization credibility. So we did not close our doors, because to help someone to know their human rights, you must first unburden their soul, approach them as a human being, get them to see that they have the right to suffer, and to come out of that suffering and still be a winner. ${ }^{89}$

Another activist from a large organization in an urban centre highlighted the problem of a project-driven approach, but equally of not only ordinary people's erroneous perceptions of activism and volunteering but of the same false ideas among civil society actors too. She recognized the importance of volunteering as something beneficial for both the community as a whole and the individuals who volunteer, who manage to step away from the common understanding of volunteering as a purely non-profit activity. In contrast to some activists of an older generation, she did not criticize the younger generation of women for not understanding activism and volunteering:

'Project limitation is a big problem, and a general problem is how we perceive working in NGOs. For example, an elderly woman asked to volunteer with us, which is really cool but also rare because most people think they will gain some material benefits from volunteering. They think there is no sense that you should come and

88 Interview conducted on 3 February 2011 in Sarajevo. In 2018, the $13^{\text {th }}$ Pitchwise Festival, a festival of women's arts and activism, took place in Sarajevo, with a focus on 'Witches' Ball "Fairy Tales and Folk Songs" - Deconstruction of Patriarchal Norms', cf. Thirteenth PitchWise Festival of Women's Arts and Activism in Bosnia and Herzegovina 2018!, Fondacija CURE, http://www.fondacijacure.org/index.php?do=article\&article_id=1033.

89 Interview conducted on 26 March 2019 in Tuzla. 
use your free time for the common good, without any compensation. But it is all connected, because if we do not have enough projects to pay our employees, the survival of the organization is in question. There is no awareness that "OK, if the project does not go through, we can still do a lot of things". We are still a long way away from that, because civic association is still new to people. Before the war we only had the Red Cross and folklore societies, so we are still wondering how to deal with these new kinds. However, now that the younger generations are having more to do with it, they associate the pleasurable with the useful, they experience volunteering as a plus which they can then put on their CVs. And they are gaining experience and a different perspective on how an association works. We are seeing a generational shift. The women's movement is often identified with a couple of names, women who got it up and running, the ones who organized the first inter-entity meetings and exchanges. Now, new young women with different perceptions and ideas have come on the scene and that is brilliant, that is the power of the women's movement. I do not know what form it will take, but the movement is now in another transitional period-like everything in $\mathrm{BiH}{ }^{90}$

\section{Women's Networks}

Research on women's networks provides important additional data on civil society values such as solidarity, equity, self-help and the notion of volunteering. It is important to note that women's networks are considered the most sustainable of all the networks that have emerged in $\mathrm{BiH}$, of which one estimate claims there are about thirty. However only a small number of them existed for more than ten years, or longer than the original projects that created them. Only a small number of networks lasted, such as those of female activists which were 'the result of genuine conviction of the members on the need for existence of [a] permanent mechanism of cooperation, harmonization of a unified platform of action, coordination of activities and unified approach towards the government institutions'.$^{91}$

Different attitudes to networks too are discernable among women, depending on whether they worked in larger or smaller organizations. Their views of the functioning of networks differed, and of their activities and the contributions of their members. In certain networks, one larger organization deals with coordination of activity while in others there is a separate coordination committee. Most networks are informal since there is no legal requirement for networks to be registered.

The 'Women's Network' (Ženska mreža) consisting of more than fifty organizations, is the largest of those I analysed..$^{92}$ Among other things it strives very

\footnotetext{
90 Interview conducted on 14 September 2011 in Banja Luka.

91 Žeravčić, Mapping Study of CSOs in Bosnia and Herzegovina, 6.

92 Cf. the Women's Network's website, http://zenskamreza.ba/.
} 
actively to raise awareness of and spread feminist values through protest activism. The Network is deeply appreciated among its members, who work in different organizations, to the point that it is sometimes described as a women's movement, rather than merely a network. However, some consider the term 'movement' an exaggeration, for as a few activists underlined, 'a network is not the same as a movement'. In an interview conducted in 2011, an activist from the coordinating association highlighted the contribution of her own organization to the Network, in terms of financial, human and other resources. During our interview, she expressed the significance of the contribution and the volunteering of her own organization, which is one of the largest women's organization in $\mathrm{BiH}$ : '[...] it was us who did everything else, you see; this is a women's network, we even paid with our own money, to let the Network's unity show. They all said "Great that you did it", never mind that no one asked how much it cost!'93

The looseness of the structure of the Network and its more general goals mean that members of other organizations do not feel excluded. One activist from an organization which is a member of both the Women's Network and another, stressed that the 'Women's Network' has a greater feeling of solidarity. ${ }^{94}$ She described the Women's Network as more dedicated to protest activism; she said that each organization is engaged in protest volunteering, although not to the same extent, and that they use a combination of 'cyber activism' and 'face to face activism'.${ }^{95}$ One thing about the contributions of different associations is that the Network's principles are clearly feminist. On sensitive questions such as LGBTQ rights, not all organizations are ready to join in with the writing or distribution of protest statements, which naturally raises questions about the precious sense of solidarity as well as the problem of a perceived hierarchy among organizations. Activists from the Network's core organizations highlight the value of protest volunteering, whereas an activist from a member association working in a smaller local community underlined some of the problems they encounter:

'We had a meeting of a network of women's organizations and we decided to protest during sixteen days of activism, and to organize women to go to Sarajevo. But the question is, how many will respond? People are scared. We are back to where we were when we started in 1998, and those were tough times. ${ }^{96}$

\footnotetext{
93 Interview conducted on 3 February 2011 in Sarajevo.

94 Skype interview conducted on 1 June 2017 with an activist from Zenica.

95 Jacob Mwathi Mati et al., Social Movements and Activist-Protest Volunteering, in: Horton Smith / Stebbins / Gratz, eds, The Palgrave Handbook of Volunteering, 533.

96 Interview conducted on 22 October 2011 with an activist from Višegrad.
} 
Another women's network is the RING network which works in the field of anti-trafficking. ${ }^{97}$ It consists of ten organizations, so it is much smaller and has clearer goals and structure than the all-encompassing Women's Network. RING has tried but failed to register, which caused great difficulty for the larger organizations that had voluntarily paid for RING's effort. Although RING's structure is clearer, nevertheless the gap is more visible between the capacities of its various members. Activists from larger organizations sometimes say that they give more to the network than they receive and that smaller organizations are always wanting to be included in different activities while lacking the resources to contribute to them. That also calls into question the value of the notional solidarity and the problem of hierarchy in the network. Activists from the larger organization said:

'We all have expertise, but four organizations bear the brunt of the work, and the rest rely on their competences. While the network mostly contributes knowledge, we did not really get any additional knowledge back; for us it feels more like we are being drained. But we chose to associate ourselves with the mission of the network, and we do our best. ${ }^{98}$

There is volunteer protest activism too, but some activists in the network think it a waste of time: 'Handing out leaflets annoys people, sometimes they have even been aggressive when we have approached them, because all manner of things get handed out. In any case, my office is full of leaflets; I could spend all my time handing them out. ${ }^{99}$

A third network is the Roma Women's Network (Ženska romska mreža) which is dedicated to improving the position of Roma women in Bosnia and Herzegovina. ${ }^{100}$ Being doubly marginalized, Roma women see the network as a secure and supportive space and its members describe its as a family. Its umbrella organization is one of the strongest women's associations in $\mathrm{BiH}$ and its leader is a well known face in civil society. She highlights that each of the ten member associations of the network does its bit, but that her own organization contributes the most:

'Of course, in every network one organization pulls the most but the others contribute what they can. We know more or less who has what capacities, because we have been together for longer than just a year. For more serious things we engage a stronger organization but others make their contribution and pretty much everyone is included.

\footnotetext{
97 Hopes Betrayed. Trafficking of Women and Girls to Post-Conflict Bosnia and Herzegovina for Forced Prostitution, Human Rights Watch, 14, no. 9 (November 2002), 11-12, https:// www.hrw.org/report/2002/11/26/hopes-betrayed/trafficking-women-and-girls-post-con flict-bosnia-and-herzegovina.

98 Skype interview conducted on 1 June 2017 with an activist from Zenica.

99 Skype interview conducted on 1 June 2017 with an activist from Zenica.

100 Cf. the Roma Women's Network's website at https://www.zrm-uspjeh.ba/index.php/en/.
} 
[...] We do not have nor do we need money for every activity. We all say, for example, "Girls, we can't all go to parliament!", so we agree who will go. And we talk about it and agree what the topic of the meetings will be.' ${ }^{\prime 101}$

There is indeed a hierarchy in this network between stronger and weaker organizations, but given the ever-present marginalization of Roma women in society it is not perceived negatively, for the women feel empowered simply by being part of the network. The members also express solidarity with other CSOs representing the Roma population. While men from Roma associations are often perceived as being not so much supportive as quarrelsome and bossy, there are exceptions. A Roma woman from the Romkinja association from Bijeljina (Udruženje Žena Romkinja Bijeljina) emphasized during our interview with her that the Roma Association for the Promotion of Roma Education Otaharin (Udruženje Otaharin) helped by sharing its premises with her own association. The men also volunteered assistance with general know-how:

'I have no office of my own, I use Otaharin resources. There is a social worker in Otaharin, a psychologist, and a lawyer, so if I need to use those services they are all

Otaharin's. To put it simply, they just help me with anything I need. The psychologist has had more than twenty conversations with Roma women who have come to my association. I asked them to talk to him [the psychologist ...]. I even got volunteers from Otaharin for a street action, as the women who are members of my association are also employed in Otaharin and they are willing to help us. ${ }^{\prime 102}$

Despite the differences I found among the networks I analysed, I saw similarities in perceptions depending on associations' capacities, which affected their positions and roles within the network. Women activists from larger organizations tended to stress that their contributions were voluntary and sometimes criticized smaller organizations for not being dedicated enough or not recognizing the larger organization's efforts enough. Activists from smaller organizations tended to appreciate the work for the network of the activists from core organizations, but also to raise concerns about, for example communication and inclusiveness in decision making. Volunteer work in networks includes protest activism and contributions of technical and human resources in network activities. However, the loose structure of networks sometimes causes misunderstandings among members, which calls into question how much solidarity and reciprocity there really is. Nevertheless, the fact that they have succeeded in enduring for so long indicates that networks are more than a temporary project, and that positive feelings, mutual support and cooperation do indeed contribute to their endeavours.

101 Interview conducted on 13 June 2017 in Zenica with an activist from Tuzla.

102 Interview conducted on 26 February 2019 in Sarajevo with a woman activist from Bijeljina. 


\section{Conclusion}

Women activists in $\mathrm{BiH}$ have contributed a great deal to the development of civil society and to the introduction of a number of laws designed to improve the position of women. Things previously considered private matters or even unimportant, such as domestic violence, or the number of women active in political institutions, are now of public concern. Women's CSOs have grown from informal and mostly humanitarian groups during the war to become specialized organizations, although they continue to help people in need in their communities and among the women they work for. Despite such contributions however, the still prevailing donor-driven approach has led to competition among women's groups, just as among other civil society groups. CSOs are sometimes perceived as opaque, closed to outsiders and so not encouraging of people who might otherwise wish to volunteer. Government policies too tend not to encourage voluntary work, funding favouring instead associations such as veterans associations which are open to manipulation by political parties.

Nevertheless, women activists have succeeded in carrying out diverse activities as volunteers, attempting to overcome the limitations of the 'projectitis disease' that we so often heard mentioned as an obstacle to their work. However, there was a difference in how they understood the voluntary work of their own and other organizations, especially depending on the size of the CSOs concerned. Activists from larger organizations with sufficient funding try not to depend on funding for every one of their activities, and emphasize their own voluntary help to other women's groups. Activists from smaller CSOs highlight the dedication and support among their own members and beneficiaries, in activity not based on projects. All our interviewees connected volunteering both with positive values such as solidarity, commitment, and negative trends like fragmentation and hierarchy. Both withdrawal of funding and orientation towards EU projects widen the gap between smaller and larger CSOs, because EU projects are more time-consuming and demand more skills, organizational, technical and otherwise.

For that reason, government institutions and CSOs alike should promote volunteer work as mostly having to do with values. Through volunteering the general public could learn skills important to a democratic society and necessary for its consolidation. Trust in CSOs is presently rather low, so it would be good if that were to change. Solidarity and visibility could be increased if larger organizations were to offer more help to organizations possessing fewer resources and capacities, to prevent them from being obliged to shut down. As I have shown, certain associations do indeed feel quite abandoned. Activities must become less project-based, and organisations must promote 
within networks the activities those networks pursue. That will increase trust and solidarity and improve the commitment of network members. For their part, associations could also become more persistent in seeking government support, especially at local level, which would help them overcome their feeling that they are living in a parallel universe, separate from most citizens and their everyday problems. Making a contribution for the benefit of the local community must become more visible, so that it can create additional motivation for others to join, while the very idea of volunteering in all senses of the word must be discussed more widely. It is not only activists who must talk about volunteering, but society in general.

\section{CORRESPONDING AUTHOR}

Zlatiborka Popov-Momčinović University of East Sarajevo, Faculty of Philosophy, Alekse Šantića 1, 71420 Pale, Bosnia and Herzegovina.E-mail: zlatiborka.popov.momcinovic@ff.ues.rs.ba 